Kohl: a Journal for Body and Gender Research Vol. 4, No. 1 (Summer 2018)

\title{
The Required Labels
}

Esraa Husain 
You may say that I am an "outspoken person," and I find myself wondering: do you mean that I am talkative? Courageous? Noisy. Honest. Even maybe too honest, whatever that means. I do not particularly disagree with you but I am not sure it is an accurate denominator. I remember certain incidents where I would not necessarily refer to myself as "outspoken." You may say that the past should stay in the past, and that you can only change the way you relate to it. But what if I told you I cannot relate to it? Today, I am different from two years ago, two months ago, two days ago. I evolve.

\section{5}

You walk towards me with your little swords and stars pinned on your shoulders. You call me names, but "outspoken" is not one of them. I mention my education status and my job, so you may think of me as normal, in your definition of normal. I stoop to your level and say you are right. Release me. I beg. You may have asked questions. I cannot win this battle, how could I? I find myself powerless, not so "outspoken" now. You ask more questions. Invade. Ask about my outfit, body shape, height, and throw in the additional comment about my facial features when needed. I secretly hope this interrogation will come to an end. I should be obedient to make you let go. Should I be polite? Never polite enough, you may say. I am naïve. This is not you. You say. This is not you. You repeat.

"Who are you? You look different than the picture on your identification card." One of you asked. "Why are you like this?" One of you interjected.

There are brick walls with barbed wire surrounding them. You go through the main gate, leaving behind the watchtower. There are small rooms painted in grey with dark wooden desks inside them. Pearl-white dishdashas ${ }^{1}$ are on the black leather chairs. Hands are playing with a Kahraman misbah. ${ }^{2}$

"What do we have here?" You lift your dishdasha to your knees - revealing your hairy legs - and spread your legs as wide as possible. A misbah hanging around your thumb. You gaze at me. "What are you then? Tell me what I am looking at." You demand. You flip the misbah to the right. You flip the misbah to the left. "You think we don't know you?" You accuse. A satisfied smirk appears on your lips. I feel cold. You whisper prayers to your god. You stand up. The misbah is now resting inside your pocket. You ask.

"If I didn't know your name I would call you a Mohammed, are you a Mohammed?"

"Who is Mohammed?" I manage to reply.

\footnotetext{
${ }^{1}$ Dishdashas are traditional Kuwaiti dresses that come in different colours: light colours like white and faded yellow in the summer and grey and brown in the winter. They are only worn by men. They can be worn in all occasions such as family gatherings, work, and weddings.

2 Misbah is the Arabic version of rosary. Usually religious men carry it in their hands. However, within the Kuwaiti communities, it is common for men to carry it with them. While it is usually seen with men who wear Dishdashas in Kuwait, men wearing casual clothes sometimes carry it as well. It symbolises manhood and masculinity and it is considered a traditional item.
} 
"You see! You are not a Mohammed." You win. You order to get me prepared. Yes, sergeant. Again, you

ask. "Have you ever been transferred?"

"Transformed? No." I hesitate.

"Did you get transferred before?"

"Why would you say that? It's only a haircut." I explain.

The words transferred and transformed in English both translate to the same word in Arabic. Tahwil. تحويل. I do not understand which one you are referring to. You say you are asking about the transference to the Criminal Department. I think you are asking about the physical transformation. I do not identify as transsexual I say to myself. More humiliations for your own personal amusement. You may have asked me to write down my name, date of birth, and nationality. Why should I write that? I resist. "Write down: I pledge." You preach. "That I won't imitate the opposite sex in dressing and appearances. If it occurs again, I will be charged with imitation and detained for six months, and/or pay 1000 Kuwaiti dinars in court. Are you done?" I nod but you do not see me. You do not want to look at me. You disapprove of my existence and you do not want to acknowledge my presence. I think of your words, and what I know about this law based on an Islamic Hadith; hundreds and hundreds of years ago, a prophet claimed that a god curses people who imitate the "opposite sex," and this was passed on to other religious men, and today still, many believe in it, religious or not. Today still, article 198 of the Kuwaiti penal code criminalizes people like me. Today still, I must conform to the heteronormative structure of your society, but I fail. You ask again.

"Are you finished?"

"Yes." I give up.

"Sign your name."

I hear you, but I do not want to. You invalidate my existence and my identity. I am therefore not compelled to listen to your orders. Each one of us has their own revolutions and little acts of defiance. I want to write another name so that I can pretend it is not happening. Not to me. I say. Not me. I repeat.

\section{7}

For all the non-binary, the androgynous, the transgender, and the gender nonconforming individuals. For the ones who are hiding at the margins of their societies. For the unloved. Our silence ties us all together. Together we break it. Together we write to transcend limitations. We forgive ourselves for the times we questioned our validity. We have a right to our emotions. Be it fear. Rage. We thrive after the setbacks. We are the rebels, the conscious of the unconscious societies. We now know that bullying and abuse come from families, partners, and governments as well. We learn to walk away from what threatens our existence. We are powerful, and we are ready for what is yet to come. 